\title{
Equal Opportunity as a Matter of Public Interest ${ }^{*}$
}

\author{
An Analysis of Institutional and Social Mechanisms \\ MARTINA MUSILOVÁ ** \\ Institute of Sociology, Academy of Sciences of the Czech Republic, Prague
}

\begin{abstract}
The article analyses attitudes to equal opportunities for men and women in Czech society, also against the background of mechanisms of the institutions of public interest. The author works with two hypothetical models, the first of which is the basic model of the general mechanism of the implementation of equal opportunities as a matter of public interest. This is compared with a second model which seeks to show how this in fact works in the Czech Republic. She then goes on to describe differences observed, suggests possible explanations for these, and outlines the factors which are specific to the Czech environment. In the conclusion she looks at the parties involved in the mechanisms investigated, and the way they conceive of and evaluate actions contributing to the implementation of equal opportunities in the Czech Republic.
\end{abstract}

Czech Sociological Review, 1999, Vol. 7 (No. 2: 195-204)

In analysing institutional and social mechanisms of the construction of public interest in Czech society in the 1990s, I start from two basic premises. The first is that public interest is a statement of the preferential interests of society and concerns the redistribution and securing of the public wealth which society uses as a whole or in parts. Secondly, the formulation of interests is a complicated process which has two principal sources. The first is the aspirations of individuals to satisfy those needs which are beyond their personal capacity. In the second case public interests are derived from the action of social, i.e. supra-individual, factors which determine social development. These are usually formulated by institutions (political, cultural, civil, constitutional, etc.).

In a transitional society public interest expresses:

- needs which concern large social units (groups or society as a whole)

- values which society is aspiring to

- the defence of social needs and values against threat [Purkrábek 1996: 78-79].

From the point of view of public interest theory, this is an important definition and specification of new dimensions of public interest. These are processes which are shaping social reality on the level of citizens in the 1990s. Public interest was a much-used concept during the state socialist period, but although the governing elite frequently referred to it, it did not meet the basic theoretical criteria governing it, that is:

- directing policy towards the development of society and the resolution of its actual problems;

- creating a free, democratic space for social and political expression;

*) This research was supported by grant no. 403/97/0586 "The Position of Women Graduates in Czech Society in the 1990s" from the Grant Agency of the Czech Republic.

**) Direct all correspondence to: Martina Musilová, Institute of Sociology of the Academy of Sciences of the Czech Republic, Jilská 1, 11000 Praha 1, e-mail musilov@soc.cas.cz 
- guarantee open access to information and freedom of expression.

In the course of the current economic, political and social transformation of Czech society in the 1990s, the areas that have been publicly recognised as of interest are those which are important for the formation of the new social order and whose neglect would mean a threat of social anomie. The following processes have had priority:

- establishing democratic principles in the Czech constitution and other laws;

- creating political plurality of parties and movements;

- constituting a market economy and market environment.

The developed democracy and the presence of women on the labour market in developed European countries has led to equal opportunity for men and women becoming a matter of public interest. The mechanisms of public interest which concerns the development of equal opportunity for men and women in the Czech Republic will be analysed in this article. I have worked with two hypothetical models of the location of this public interest in this country. In the second part of the article I will describe the differences observed, suggest a possible explanation for these and outline the factors which are specific to the Czech situation. The conclusion will be devoted to the actors in the mechanisms researched and how they conceive of and evaluate the activities which contribute to the spread of equal opportunities in the Czech Republic.

\section{Models of the Implementation of Equal Opportunities}

In the Czech Republic, equal opportunities are not conceived of or recognised as a matter of long-term public interest. ${ }^{1}$ It is difficult for interests of this type to become established and since they are generally a case of ideas that affect the future, and the power sphere tends to underestimate their importance. Nor is public support for them overly strong, since people do not see these problems as urgent or as directly affecting them (unlike matters of short-term public interest). Approaches to the question of equal opportunities vary. $^{2}$ The most common approach at the outset is that which I have here termed Model A.

Model A shows the mechanism by which equal opportunities become established as 'classical, long-term interest'. Information dialogue and public participation play a fundamental role in identifying and formulating public interest. In the course of this process the bearers of this interest become actors on the highest level. There may eventually be a problem of identifying the established interest - most often on the level of political parties. These should be able to recognise which values are the most important in society,

1) The most important factor in identifying and then establishing public interest in the Czech Republic is timing. The time-structure of public interest can take three forms:

- short-term - identifiable on the basis of existing social problems or tensions and functional needs of society;

- long-term - arising rather from values that the society propagates, as for instance with investment in future development (these values are often stated in party political programmes);

- mid-term - a combination of both approaches - generally a case of existing values which have repeatedly failed to gain recognition or of the re-emergence of social problems.

2) In a discussion of equal opportunities it is a sine qua non condition that a given society fulfils the preconditions of an open society. Public interest is based on the existence of a public sector and assumes the functioning of a market economy. 
since only those which are really recognised become the subject of public interest. The decision-making bodies gradually become aware of this interest and determine whether it will be accepted or not. Whatever they may decide, it is important that the public be aware of the result, since collaboration is essential for the establishment of public interest.

Model A.

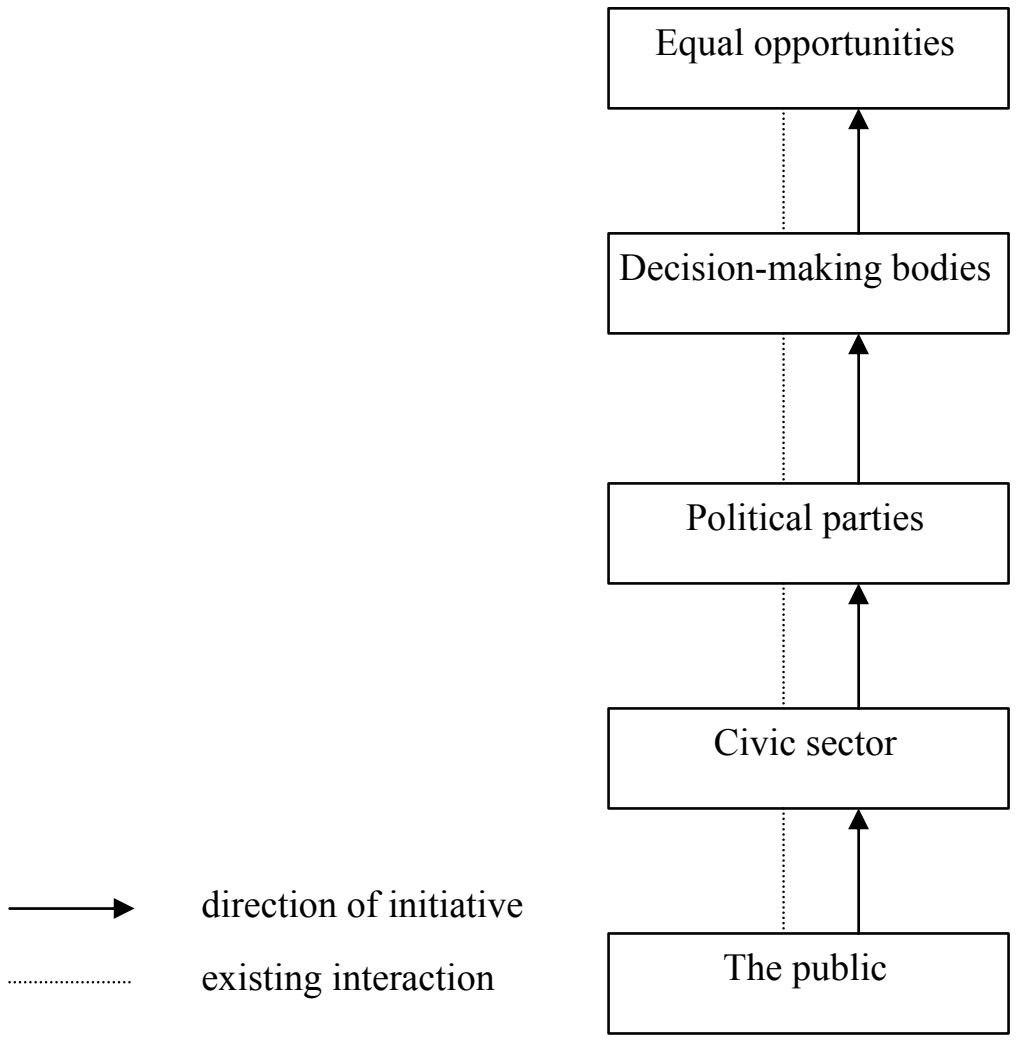

The problem in the Czech Republic is somewhat different. Equal opportunities (recognised as a matter of public interest) are an instrument for fulfilling another matter of public interest, i.e. entry into the European Union. This is at present a priority for midterm interest, since the Czech Republic is actively seeking membership. ${ }^{3}$

There is now a very particular situation in the Czech Republic. On the one hand there is formal support for equal opportunities on the level of power-holders, but at the

3) Equal opportunities have not had an unbroken development even in the European Union, but there is now institutional support for them and forces which have gradually raised them to an EU priority. This public interest was originally voiced by individuals who demanded equality for women and men. It was a long time before it was in fact recognised as a matter of public interest and put into practice. There has however been a gradual transformation into a matter of social interest [Naisbitt and Aburden 1992, Purkrábek 1996, Rees 1998, Scruton 1990, Veselý undated]. This was primarily due to the attempt to resolve problems linked with unemployment and poverty, which affected women more than men and led to their social exclusion. Many member states accepted the principle of equal treatment when the European Community was founded in the 1950s, but the principle was in fact only fully established at the end of the 1980s [Rees 1998]. 
same time one important precondition for its recognition as a matter of public interest is lacking. This is the support of the public. The Czech public, both male and female, still does not see equal opportunities as a question which requires a solution. Both men and women have a sense of equal rights, but at the same time they have no difficulty in accepting the roles which society prescribes for them. Nor are the factors which determine the position of women in society as it is at present seen by the public as a source of conflict. ${ }^{4}$ This degree of inconsistency in opinions is typical of Czech society and its roots probably lie in the so-called 'post-communist syndrome'.

Model B.
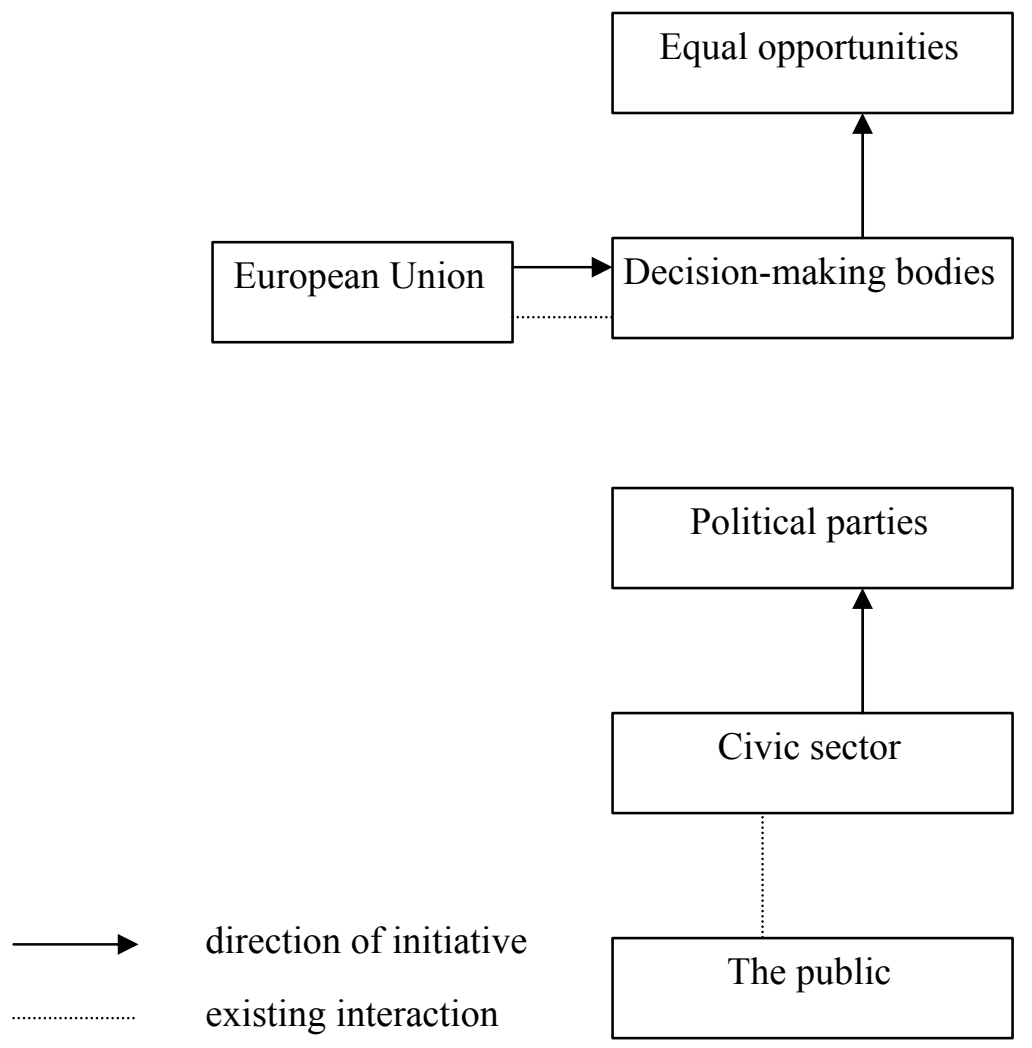

Mechanisms characteristic of the Czech Republic are depicted by Model B. Here there are apparently three unconnected sectors. At the bottom there is the public, which has as yet presented no demands for equal opportunities. In the middle, equally alone, stands the so-called non-governmental sector, which in normal circumstances acts as a type of 'mediator'. However, it only fulfils its functions in part, as some signals emerge on the level of the civic sector, but they come up against the barrier of the political parties. ${ }^{5} \mathrm{~A}$ further

4 ) Czech women are, however, conscious of this to a certain degree, as 55\% of respondents would welcome special measures to help women, particularly relating to work and maternity (although only $15 \%$ of women answered "definitely yes") [Kuchařová and Zamykalová 1998].

5) No political party has as yet expressed explicit support for the principle of equal opportunity. This goes both for the parties of the former coalition, which accepted the Government Declaration 198 
gap appears between them and the decision-making level (government, parliament). Paradoxically, it is the latter where the attempt to establish equal opportunity is strongest, since the decision-making sphere is greatly influenced by its undertakings to the EU and various international legal documents. ${ }^{6}$ Meeting these formally will bring the Czech Republic closer to entry into the EU, which is an aim which is dear to the heart of the Czech Government.

Identification and realisation of matters of public interest can only be effective when it is the result of a consensus of political partners. For this reason, the absence of any participation by individuals and interest groups is a negative sign. The government can then slide into a state of what is sometimes termed in the literature [Howlett and Ramesh 1995] as "agenda-setting". In practice it means defining public interest as a political agenda for the government. It is the "recognition of problems by the government". The government or public officials themselves decide what they will take as being in the public interest. The drawback of this approach is its narrow underestimation of public policy, which does not solve the problem of whether and to what degree this government agenda represents the real problems or interests of society.

In the Czech Republic, equal opportunities policies have become an instrument for 'fulfilling' one of the tasks of a pre-emptive strategy. There is, of course, the danger that the means will become an end and that equal opportunities will stagnate at the level of a proclamation.

Why then does the Czech public maintain its distance and not have its own position on this question? What factors are concerned and how can they influence the approach of the Czech public to equal opportunities.

a) Historical tradition and the cultural pattern of behaviour. "At the turn of this century the Czech public showed exceptionally strong support for women's emancipation" [Havelková 1995: 35]. The women's movement at that time was very active and launched a struggle for universal suffrage, which was only attained after Czechoslovakia was established. In the declaration of the independence of the Czechoslovak Republic on 18th October 1918 it says: "Women will be politically, socially and culturally on a level with men". Article 106 of the first constitution from 1920 states that "There shall be no privileges pertaining to sex, family or calling". The tradition of the First Republic was disrupted by the emergence of communism, but the percentage of working women continued to be high and this did not change greatly even after the economic transformation.

b) The economic situation and the development of the country. The beginning of the 1990s saw both social transformation and economic reform in this country, the latter aimed at resolving the country's difficult economic situation. At that time policies were concentrated on economic goals and the development of the civic sector and public interest receded into the background. The economic changes had a high level of support among the public and were seen as a necessity. In such an atmosphere, questions relating to women were seen as exaggerated and marginalised.

on the Equal Rights of Men and Women, but also for the programme of the governing Social Democrats, where there is only a passing reference to equal opportunities.

$\left.{ }^{6}\right)$ For example, the Convention for the Elimination of Discrimination against Women (CEDAW), which the Czech Republic subscribed to 1982. 
c) The political regime of the state and society. The equality of men and women had an important place among the aims of the former communist system. There was, however, a fundamental flaw in that the totalitarian state decided without the participation of the parties who would normally become involved in a democratic system, in this case men and women. The general presence of women in society was a part of the official ideology of the communist regime in the Czech Republic. The relatively high percentage of women in social and political life and in the economy was however due to state intervention and regulation. This contributed to a declining interest among women in their own emancipation, against a background of relatively equal but low standard living for all and the paternalistic approach of the state. In addition, all the various approaches and conceptions such as the feminist movement were 'ideologised'. This contributed to an ironic and pejorative view of women's questions which has largely continued even after the changes. In a survey by Lidové noviny, for example, one of the women questioned said:

"I am against any -isms. Such a movement is not important for what I call the quality of life." ["Profesionálky" 1999]

Dahrendorf compares the transition from an authoritarian regime with a centrally-planned economy to a democratic society with a market economy to a hyperbole. He believes that political institutions can be changed in six months, economic relations in six years, and people's habits, attitudes, behaviour and values in sixty years. [Dahrendorf 1991].

d) The cultural level and quality of life in a given country. This factor has a clear influence on determining those matters which have a chance of being recognised as in the public interest. In this respect it is clear that the establishment of equality can be of concern to those societies which have attained a certain level and no longer have to resolve the primary problems. One reason why equal opportunities are not clearly understood in this country is that there are still enough other problems which affect many people (bad economic situation, unemployment). Here it is possible to see an analogy with Maslow's theory of needs; higher needs can only be satisfied when the fundamental ones have already been met. Some people also feel that feminism can only interest women who already have a certain level of security. The owner of one large cosmetic firm expressed this clearly:

"Feminism is like a superstructure. It is only women who have no other worries that can think about it." ["Profesionálky" 1999]

e) The country's geopolitical situation. Until recently a great deal of energy in the Czech Republic was spent in measures relating to the country's entry into NATO. The wish to join the alliance was one of the government's main priorities. Since this aim was achieved in March this year, it can be supposed that the political sphere will now turn its attention to other areas.

f) Responsibilities relating to international documents. The government began to take a systematic approach to its responsibilities relating to the position of women in society in the second half of 1997. In addition to the Czech Republic's undertaking to fulfil recommendation 4 of the UNO World Conference on Women, which took place in Peking in 1995 , and the convention on eliminating all forms of discrimination, it also tried to meet the general conditions for EU membership by a public declaration of equal opportunities. Until that time the activities of the Czech government were sporadic and the women's 
question was not a subject which interested the government or de facto even the public. ${ }^{7}$ Two years after the Peking conference, however, it was no longer possible to postpone the matter and the first steps had to be taken. A further impulse came from the need to harmonise legislation in this area with that of the European Union. This led to formal responsibility for coordinating this policy being given to the Minister of Work and Social Affairs at the beginning of 1998. At the same time all government departments were directed to collaborate with non-governmental women's organisations and the Minister of Work and Social Affairs was directed to draw up a concrete programme for this area. As a result the Department for the Equality of Men and Women was set up within the Ministry of Work and Social Affairs on 1st February 1998. This department prepared a proposal for government statement no. 236/1998, "Government Priorities and Approaches to Establishing Equality between Men and Women", which was the first official document issued in the area.

In certain countries and societies there may be other specific factors which have a decisive influence on both the selection and the presentation and realisation of matters of public interest, ${ }^{8}$ but the above factors are the key ones in the Czech situation.

\section{Actors}

In considering who are the parties involved in these mechanisms, Table 1. provides a summary of them and their activities in the implementation of equal opportunities.

It cannot be expected that all these parties will completely fulfil their responsibilities all at once. As Model B showed, this is not in fact possible in the given situation.

In the Czech Republic there is a situation in which equal opportunities policies are implemented 'from above'. For this reason they remain confined to the basis of legislation, and decision-making bodies do not furnish the space to link up with all the parties mentioned above. In practice this means that there is no prevailing mechanism which would transform theoretical concepts into practical steps, investigate and evaluate women's concrete problems, and take measures to solve them. The inconsistent implementation of equal opportunities on the part of decision-making bodies is due to the lack of links between the basic levels. This leads to a rigidity of public attitudes, since the public does not at the present time have access to information as to what the concept of equal opportunities in fact means and what they have to gain from it.

\section{Conclusion}

At the end of the 1990s the Czech Republic stands on the threshold of European integration. Membership of the European Union, which is being actively sought, will require a pre-emptive strategy in relation to certain demands. For the Czech Republic to be accepted by the European Union, it must first come to terms with a number of concrete tasks. In the social policy field this is a question primarily of harmonisation and coordination of Czech regulations with the social dimension of EU policy.

\footnotetext{
${ }^{7}$ ) In the early 1990s the greatest attention to women's questions came from non-governmental organisations.

${ }^{8}$ ) This can be seen from the way the question of equal opportunities is dealt with within the European Union. Even though it may seem to act as a single unit, there may be considerable differences between the various member countries. In countries such as Spain, Portugal or Greece, the implementation of equal opportunities is proceeding at a very different rate. [Rees 1998].
} 
Even if the social policy area is not a major obstacle to our entry, we still lag behind the EU in the implementation of equal rights for men and women. Recent years have seen the development of an active European policy of equal opportunities within the European Union. The nature and form of this policy are set by the attempt to define the space of action in solving problems which go beyond the national level. The inspiration by legislation on equality and mainstreaming would therefore represent an impulse towards the development of equal opportunities in this country as well.

Although the Czech government has accepted the approach of the European Union and in 1998 began to implement equal opportunities within Czech society, this process has not been entirely smooth. Behind it there is another interest which is governing the decision-making sphere. The fulfilment of one of the requirements for entry is at present both complicating and fulfilling undertakings arising from international documents. In parallel with individual phases in the creation of policy, equal opportunities policy has reached the phase of decisions, but has stagnated in the implementation phase, which is a fundamental shortcoming from the point of view of the government fulfilling its priorities. ${ }^{9}$ The vacillation and uncertainty of the institutions and bureaucrats responsible for this issue are evidence of a problem that is typical for the Czech Republic - an inadequately functioning state bureaucracy.

The solution is certainly not a one-off acceptance of mainstreaming, since this would not have sufficient support in this country. Even if the Czech public is aware of certain differences and inequalities between men and women, its attitudes are not as yet inclined towards equal opportunities.

Translated by April Retter

MARTINA MUSILOVÁ studied sociology and social policy in the Faculty of Social Sciences of Charles University. From 1997 to 1999 she worked for the Institute of Sociology of Academy of Sciences of the Czech Republic in Prague. Her main area of work is gender sociology and she specialises in questions of public and social policy.

\section{References}

Dahrendorf, R. 1991. Úvahy o revoluci v Evropě v dopise, který měl být zaslán jistému pánovi ve Varšavě [Reflections on the Revolution in Europe]. Praha: Evropský kulturní klub.

Havelková, H. 1995. "Dimenze 'gender' ve vztahu soukromé a veřejné sféry" [The Gender Dimension of the Relationship Between Private and Public]. Sociologický časopis 31: 25-38.

Howlett, M., M. Ramesh 1995. Studying Public Policy. Oxford: Oxford University Press.

Kuchařová, V., L. Zamykalová 1998. Aktuální otázky postavení žen v ČR [Current Questions on the Position of Women in the Czech Republic]. Praha: VÚPSV.

9) According to the document "Government Priorities and Approaches in Implementing Equal Opportunities for Men and Women", these priorities are as follows: (1) Acceptance of the principle of the equality of men and women as an element of government policy, (2) Legal measures to ensure the conditions for equality of men and women, and increasing the level of legal awareness, (3) Ensuring equal opportunities for men and women in entry into the economic sphere, (4) Ensuring an equal social position for women and men caring for children or other members of the family, (5) To consider women from the point of view of their reproductive function and different physiological makeup, (7) To follow and evaluate actions taken to implement the principle of equality of women and men. 
Naisbitt, J., P. Aburden 1992. Megatrendy 2000 [Megatrends 2000]. Bratislava: Bradlo.

"Profesionálky" [Professional Women] 1999. Magazín LN, 26. 3. 1999: 8-12.

Purkrábek, M. 1996. "Veřejné zájmy a veřejná politika" [Public Interests and Public Policy]. Pp. 74-118 in Veřejná politika. Studijní texty. Praha: ISS FSV UK.

Rees, T. 1998. Mainstreaming Equality in the European Union. London: Routledge.

Scruton, R. 1990. Slovník politického myšlení [A Dictionary of Political Thought]. Brno: Atlantis.

Veselý, A. undated. Přepisovat teorii veřejného zájmu [Rewriting Public Interest Theory]. (Unpublished text). Praha: ISS FSV UK. 